\title{
Pemberdayaan Ekonomi Anggota Pengajian Baitus Sholikhin Melalui Ketrampilan Shibori, Sidomulyo, Godean, Yogyakarta
}

\author{
Hasnah Rimiyati ${ }^{1}$, Tri Maryati ${ }^{2}$ \\ 1,2. Program Studi Manajemen, Fakultas Ekonomi dan Bisnis, Universitas Muhammadiyah Yogyakarta, \\ Email: hasnah_rimiyati@umy.ac.id \\ DOI: $10.18196 / p p m .34 .280$
}

\begin{abstract}
Abstrak
Program Pengabdian Kemitraan Masyarakat (PKM) ini bertujuan untuk mendorong kemandirian ekonomi para ibu kelompok pengajian Baitus Sholikhin, dusun Sembuh, Sidomulyo, Godean, Yogyakarta. Membekali ketrampilan bernilai jual agar memiliki kemampuan berwirausaha, diharapkan dapat mengurangi tingkat ketergantungan terhadap orang lain, dapat membantu para suami dalam upaya ikut andil menyejahterakan kehidupan dan pendapatan kelvarganya. Dari prasurvei yang dilakukan pada kelompok tersebut terdapat beberapa permasalahan, di antaranya yaitu: 1) kurangnya pemahaman kewirausahaan serta kemampuan di bidang pemasaran; 2) kurangnya keterampilan yang memadai sehingga belum mampu menemukan jenis usaha dan jenis produk yang layak untuk dijual. Berdasarkan permasalahan tersebut, solusinya berupa: 1) memberikan pembekalan melalui pelatihan motivasi wirausaha agar memiliki jiwa serta sikap mental sebagai seorang wirausaha. Melalui pelatihan ini peserta termotivasi untuk menjadi wirausaha, di samping itu juga mampu menggali ide bisnisnya untuk menghasilkan produk yang layak dipasarkan; 2) membekali peserta dengan pelatihan ketrampilan membuat kerajinan kain Shibori, dalam hal ini peserta ikut aktif terlibat langsung dalam membuat kerajinan kain shibori, yaitu membuat kerajinan kain dengan teknik mengikat, melipat dan mewarnai. Melalui pelatihan ketrampilan ini peserta mulai berlatih mengembangkan kreativitasnya dengan memunculkan motif baru yang bervariasi.
\end{abstract}

Kata Kunci: pemberdayaan, kewirausahaan, motivasi, ketrampilan

\section{Pendahuluan}

Pemberdayaan masyarakat adalah merupakan suatu proses pembangunan sumber daya manusia atau masyarakat itu sendiri dalam bentuk penggalian kemampuan pribadi, kreativitas, kompetensi dan daya pikir serta tindakan yang lebih baik dari sebelumnya. Sulistiyani (2014), menjelaskan bahwa pemberdayaan itu berasal dari kata "daya" yang berarti kekuatan atau kemampuan", sehingga pemberdayaan dimaknai sebagai proses untuk memperoleh daya, kekuatan atau kemampuan, dan atau pemberian daya, kekuatan atau kemampuan dari pihak yang memiliki daya kepada pihak yang kurang atau belum berdaya".

Kaum perempuan, di antaranya para ibu rumah tangga perlu diberdayakan, melalui bekal keterampilan hidup yang dimiliki dan memadai diharapkan mampu menyejahterakan hidupnya sendiri, bahkan meningkatkan ekonomi keluarganya. Perempuan merupakan sosok penting dalam menentukan kualitas hidup keluarga dan sebagai bagian dari komunitas masyarakat, perempuan memiliki peran dan fungsi yang penting. Di bidang ekonomi pemberdayaan perempuan lebih diarahkan pada kemampuan dalam mengelola usaha, khususnya untuk usaha rumahan atau home industry. Menurut IMF dalam Sulistiyani (2014) terdapat lima langkah penting yang dapat dilakukan dalam membangun kemampuan berwirausaha bagi perempuan, yaitu: 1) membantu dan mendorong kaum perempuan untuk membangun dan mengembangkan pengetahuan serta kompetensi diri mereka melalui berbagai program pelatihan; 2) membantu kaum perempuan dalam strategi usaha dan pemasaran produk; 3) memberikan pemahaman terhadap regulasi dan peraturan pemerintah terkait dengan legalitas dunia usaha; 4) mendorong dan membantu kaum perempuan untuk mampu menggunakan teknologi informasi dan komunikasi secara optimal; 5) membuat Usaha Mikro/Jaringan Usaha Mikro Perempuan/ Forum Pelatihan Usaha. 
Wirausaha merupakan kegiatan yang menyenangkan dan mudah apabila dilakukan dengan tekun, penuh semangat, dan tidak mudah menyerah. Seperti halnya wirausahawan yang sukses, mereka melaksanakannya dengan tekun dan tidak mudah menyerah meskipun harus gagal berkali-kali dalam menjalankan usahanya. Salah satu peranan penting dalam keberhasilan wirausaha adalah ide dan kreatifitas seorang wirausahawan dalam mengembangkan usahanya. Tanpa adanya ide, kreativitas, dan motivasi diri maka seorang wirausaha tersebut akan mengalami kegagalan bahkan rasa putus asa berwirausaha. Terdapat beberapa permasalahan yang menyebabkan masyarakat sulit untuk melakukan kegiatan wirausaha, di antaranya yaitu minimnya inovasi, kurangnya motivasi berwirausaha, ilmu pengetahuan yang kurang mendukung dalam berwirausaha, sementara dari pengusaha ingin sukses secara instan. Hal tersebut sangat mempengaruhi kondisi wirausaha sekarang ini.

Berdasarkan uraian diatas mengenai pentingnya peran kaum perempuan ataupun kaum ibu agar dapat mandiri dalam membantu para suami guna menyejahterakan keluarganya, maka perlu dilakukan upaya pemberdayaan kemampuan berwirausaha melalui pembekalan keterampilan bagi para ibu-ibu yang dapat menghasilkan. Sasaran objek sebagai Mitra yang dibina dalam program ini adalah para ibu anggota kelompok pengajian Musholla Baitus Sholikhin, dusun Sembuh Kidul, Sidomulyo, Godean, Sleman, Yogyakarta. Alasan memilih bermitra dengan kelompok anggota pengajian ini karena melalui prasurvei yang dilakukan, sebagian besar dari 40 orang anggota kelompok terdiri dari ibu rumah tangga yang berusia produktif, penuh semangat untuk mandiri dalam meningkatkan kesejahteraan keluarganya, mereka bersedia untuk dilatih dan dibina kemampuan kewirausahaan. Desa Sidomulyo merupakan desa yang berada di Kecamatan Godean, letaknya berbatasan dengan Kecamatan Gamping disebelah timur, sebelah selatan berbatasan dengan Kecamatan Moyudan, dan sebelah barat berbatasan dengan Kecamatan Minggir, utara berbatasan dengan Kecamatan Mlati. Melalui pelatihan dan pendampingan ini diharapkan mampu mendorong para perempuan agar dapat secara mandiri berani berlatih berwirausaha.

Pendahuluan sebaiknya terdiri tidak lebih dari tiga-empat paragraf, dan paragraf terakhir memuat pernyataan tujuan kegiatan. Isi pendahuluan mencakup latar belakang / alasan kegiatan, kerangka teoritis, dan analisis situasi saat ini, serta tujuan pengabdian masyarakat

\section{Metode Pelaksanaan}

Metode pelaksanaan pengabdian pada masyarakat dalam menyelesaikan masalah pada Mitra adalah sebagai berikut:

a. Penyuluhan tentang kewirausahaan dan memotivasi ibu-ibu jama'ah pengajian Baitus Sholikhin agar mau berwirausaha melalui usaha rumahan.

b. Berlatih mengenali dan menggali potensi diri sehingga peserta dapat mengetahui minat dan bakat yang ada pada diri masing-masing.

c. Berlatih ketrampilan yang bernilai jual melalui membuat produk kain shibori

1. Tahap-tahap pengabdian kepada masyarakat:

a. Tahap persiapan:

1) Melakukan koordinasi dengan pihak Mitra dan peserta program pendampingan, untuk mensosialisasikan program yang akan dijalankan. Dilanjutkan dengan pembentukan kelompok peserta pelatihan motivasi kewirausahaan, dan pengelolaan bisnis. Masingmasing kelompok terdiri dari 3-4 orang anggota peserta. 
2) Menentukan jadwal dan tempat kegiatan pelatihan, waktu pelaksanaan pelatihanpelatihan direncanakan pada bulan pertama.

3) Mempersiapkan bahan baku produksi, berupa kain katun polos putih, bahan pewarna kain, tali untuk mengikat kain, wadah plastik untuk pewarnaan kain, serta plastik alas menjemur kain yang sudah di beri warna, almari kaca atau rak display produk, serta peralatan pendukung lainnya (semua bahan baku yang diperlukan dalam proses produksi serta peralatan diberikan oleh tim kepada pihak Mitra berupa dana bantuan hibah kepada masyarakat sebesar 30\% dari total dana PKM).

b. Tahap Pelaksanaan:

1) Melakukan penyuluhan melalui pelatihan motivasi wirausaha dan memahami pemasaran. Pelatihan wajib diikuti oleh semua peserta yang sudah menyatakan kesediaanya. Materi penyuluhan disampaikan oleh instruktur yang kompeten di bidangnya.

2) Pelaksanaan pelatihan ketrampilan membuat kerajinan kain Shibori, materi disampaikan oleh instruktur yang kompeten dibidangnya. Peserta (masing-masing kelompok) secara langsung melakukan praktik membuat kerajinan kain Shibori.

3) Tim melakukan pendampingan pada kelompok pengrajin dalam proses produksi hingga terampil.

c. Tahap Evaluasi

1) Melakukan monitoring dan evaluasi terhadap kegiatan produksi dari masing-masing kelompok.

\section{Hasil dan Pembahasan}

Kegiatan pengabdian pada masyarakat ini bertujuan untuk membentuk pola pikir yang kreatif dan inovatif pada ibu-ibu jama'ah pengajian Baitus Sholikhin, dusun Sembuh Kidul, Sidomulyo, Godean, Yogakarta. Melalui pemahaman tentang kewirausahaan dan berbekal ketrampilan yang diberikan diharapkan dapat memberikan pengetahuan tentang kewirausahaan dan memotivasi peserta agar mau berwirausaha. Target luaran dari program pelatihan agar peserta mengerti tentang kewirausahaan dan mempunyai semangat untuk berwirausaha.

\section{Tahap Pertama:}

Pelaksanaan program terlebih dahulu diawali dengan melakukan koordinasi kepada Pimpinan Mitra ibu Haryani, untuk menyepakati waktu pelaksanaan kegiatan. Pada hari Selasa tanggal 3 Maret jam 15.30 s.d. 17.30 dilaksanakan pelatihan kewirausahaan dan pemasaran, diikuti oleh 32 peserta dari jama'ah pengajian ibu-ibu Baitus Sholikhin, bertempat di dusun Sembuh Kidul, Godean.

Materi Pelatihan kewirausahaan yang diberikan meliputi:

1. Motivasi berwirausaha

2. Menggali Potensi Diri
a. Mengenali Potensi diri
b. Cara menggali potensi diri
c. Pengembangan potensi diri

3. Peluang Usaha 

a. Analisis Peluang Usaha
b. Jenis Usaha yang sesuai dengan kepribadian

Materi Pelatihan bidang Pemasaran, meliputi:

1. Pentingnya merencanakan produk (meliputi atributnya: merek, label, dan kemasan)

2. Penentuan harga jual produk serta kebijakannya

3. Pentingnya merencanakan promosi, baik offline dengan membuat brosur, banner, poster, dan lainnya, maupun secara online.

4. Pentingnya merencanakan saluran distribusi, yaitu penyampaian produk kepada konsumennya, dengan cara distribusi langsung maupun tidak langsung dengan menggunakan perantara.
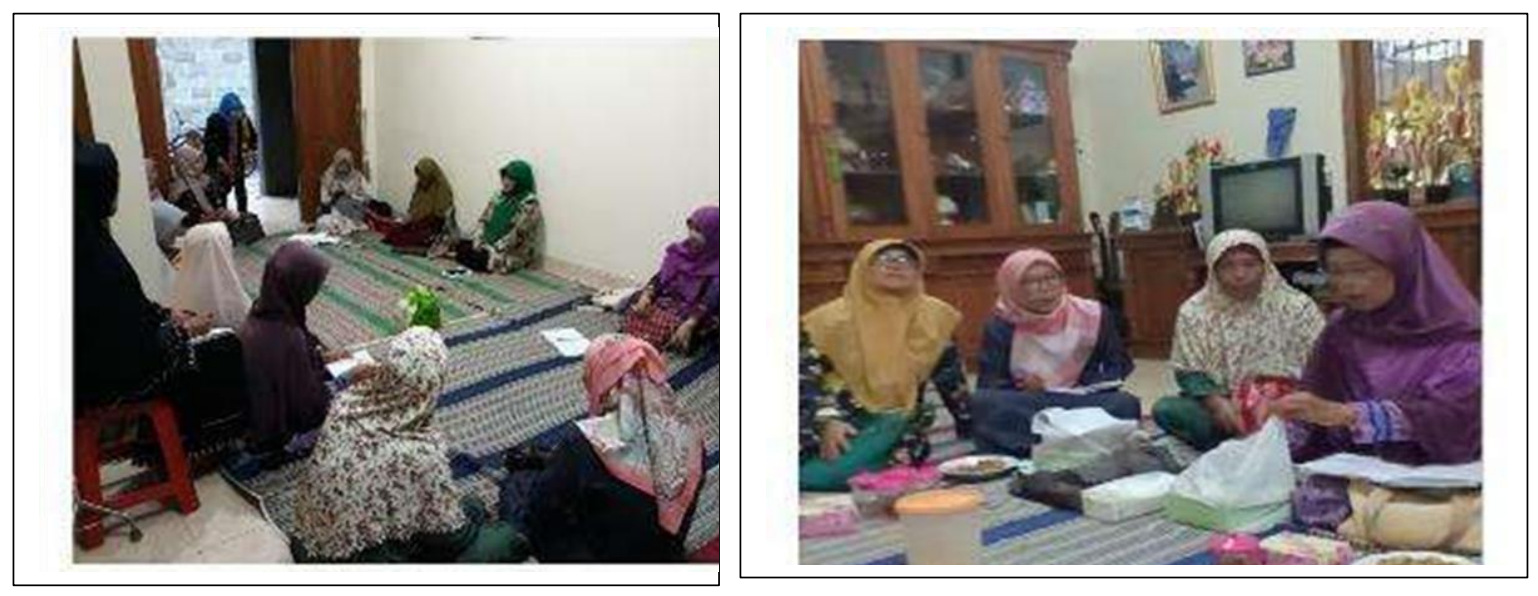

\section{Tahap kedua:}

Gambar 1. Kegiatan Pelatihan Kewirausahaan

Pelatihan ketrampilan pembuatan produk kerajinan kain Shibori.

Program Pelatihan Ketrampilan membuat kain Shibori dilaksanakan pada hari ahad, tanggal 5 Juli 2020 jam 08.00-12.00, bertempat di dusun Sembuh Kidul, Sidomulyo, Godean, Sleman, Yogyakarta, dengan didampingi oleh instruktur yang kompeten yaitu ibu Sri Jauharotul Maknunah dari Aisyiyah Cabang Godean. Pelaksanaan kegiatan pelatihan sempat diundur hingga hampir 4 bulan dari rencana semula karena adanya pandemi Covid-19, situasi dan kondisi yang tidak memungkinkan untuk mengadakan perkumpulan. Namun program tetap harus berjalan, melalui perizinan pada aparat dusun setempat, akhirnya memperoleh izin dan kegiatan dapat terlaksana dengan lancar, meskipun dengan jumlah peserta yang terbatas, hanya dapat diikuti maksimal peserta 15 orang, sementara peserta yang berminat dan sudah mendaftar sebanyak 30 orang. Pelaksanaan pelatihan ketrampilan membuat kain shibori dapat dilaksanakan dengan mengikuti ketentuan protokoler Covid-19 yang ketat, semua peserta wajib memakai masker dan face shield, menjaga jarak antar peserta, disediakan fasilitas cuci tangan, dan kegiatan diselenggarakan di area yang terbuka, di halaman pekarangan rumah ibu Tri Maryati. Kegiatan pelatihan disajikan dalam Gambar 2 berikut ini:
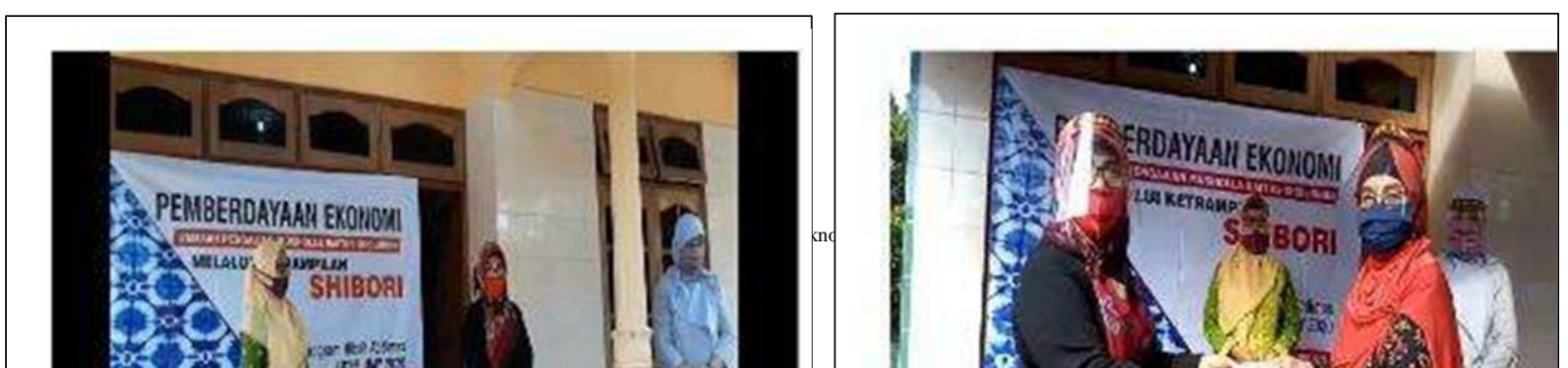


\section{8}
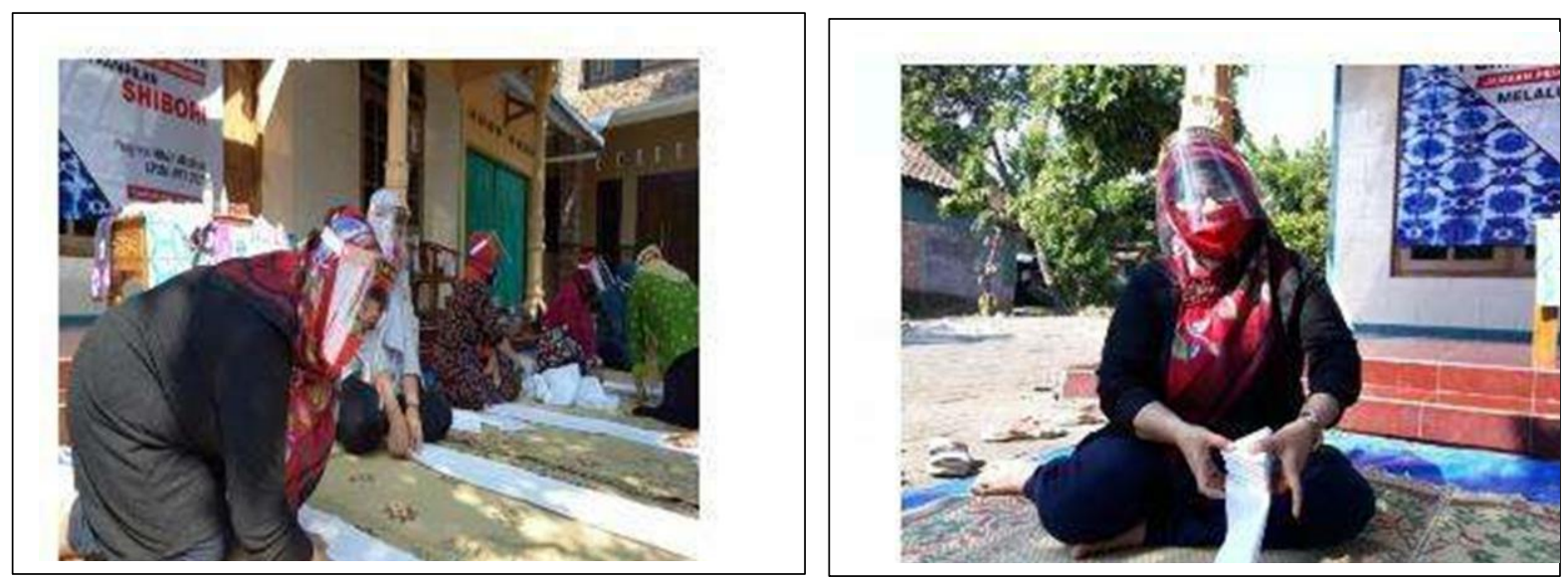

Gambar 2. Pelatihan Membuat Kain Shibori
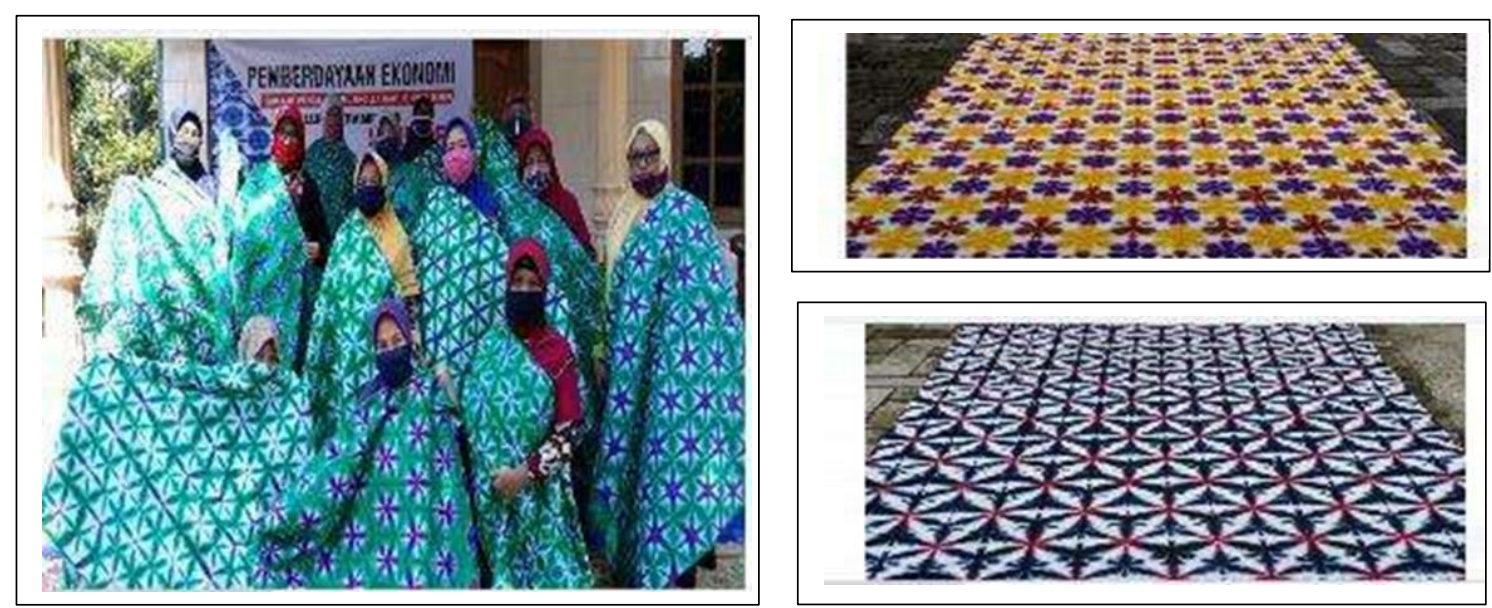

Gambar 3. Produk peserta hasil pelatihan membuat kain shibori

Penerapan IPTEK dalam program pelatihan ini adalah sebagai berikut:

Dalam proses produksi kerajinan terdapat beberapa teknik yang dapat digunakan, diantaranya teknik dasar yang digunakan untuk pemula, yaitu "Teknik Kanoko Shibori”, teknik ini disebut juga celup ikat. Beberapa bagian kain diikat menggunakan benang atau karet untuk mendapatkan motif yang diinginkan, misalnya motif segi empat, bulat, dan variasi lainnya. Dalam program kali ini masih menggunakan teknik kanoko shibori, karena teknik ini yang masih relatif mudah dilakukan bagi para pemula. Untuk tahap pengembangan selanjutnya 
dalam proses produksi pembuatan desain motif dapat menggunakan alat bantu komputer, namun untuk kebutuhan awal bagi pemula belum menjadi prioritas.

Bahan-bahan yang digunakan sebagai berikut:

1. Kain Prima putih polos

2. Pewarna kain, aneka warna (merah, kuning, hijau, dll)

3. Water glass

4. Cuka makan

5. Air

Peralatan:

1. Sendok makan dan sendok teh

2. Gelas

3. Nampan

4. Karet gelang

5. Baskom

6. Ember

Membuat kerajinan kain shibori, dibutuhkan tingkat kesabaran dan ketelitian yang tinggi, karena proses pembuatannya melalui tahap melipat kain, mengikat dan mewarnai. Kualitas hasil kain shibori sangat tergantung dari proses awal kerajinan melipat kain, komposisi warna, serta ketelitian saat mewarnai kain yang telah dilipat tersebut.

Untuk menciptakan variasi motif dibutuhkan kreativitas dalam melipat, karena lipatan akan menentukan motif yang dihasilkan.

Dalam pelatihan ini semua peserta terlibat dalam proses produksi membuat kain shibori, dengan bahan yang sama dikerjakan oleh orang yang berbeda, akan menghasilkan produk kain shibori yang berbeda, itulah seni dalam ketrampilan handmade.

Tahap ketiga:

Rencana awal pelatihan shibori diikuti oleh 30 peserta, namun karena keterbatasan izin yang diberikan oleh pihak aparat desa bahwa untuk pertemuan dibatasi maksimal hanya 15 orang saja, sehingga pelatihan selanjutnya dilakukan secara bertahap, dengan cara saling menularkan ilmu ketrampilan yang diperoleh oleh peserta pelatihan awal bagi yang telah terampil atau bahkan mahir mengajarkan ketrampilannya pada anggota kelompok yang lainnya yang belum mendapatkan kesempatan pada saat awal. Namun pelaksanaan kegiatan pelatihan ini tetap dalam pengawasan tim pelaksana.

Bagi peserta kelompok awal, berlatih membuat aneka pola lipatan lain, sehingga menghasilkan motif yang berbeda dengan komposisi yang berbeda. Peserta sangat antusias mengikuti kegiatan pelatihan membuat kain shibori ini.

\section{Simpulan}

Program Pengabdian Kemitraan Masyarakat (PKM) ini telah dilaksanakan, dapat disimpulkan sebagai berikut:

1. Melalui pelatihan motivasi wirausaha para peserta khususnya bagi ibu-ibu jama'ah pengajian Baitus Sholikhin diharapkan mampu meningkatkan pemahaman dan semangat berwirausaha. Para peserta sangat antusias dan bersemangat mengikuti pelatihan hingga selesai, baik pelatihan motivasi wirausaha maupun pemahaman terhadap pemasaran. 
2. Melalui pelatihan ketrampilan membuat kain shibori, peserta memiliki ketrampilan yang dapat digunakan sebagi bekal untuk berlatih berwirausaha baik secara berkelompok maupun secara individu. Banyak diantara peserta yang menyukai ketrampilan membuat kain shibori ini, dan berminat untuk mengembangkan motifnya, dan juga memanfaatkan kain shibori menjadi berbagai macam fashion, tidak hanya berupa pakaian, namun juga dapat membuat tas, taplak meja, mukena lengkap dengan sajadah dan tasnya, dan juga pashmina.

Oleh karena itu perlu mendapat perhatian dan dukungan untuk kelanjutan dari program pengabdian kemitraan masyarakat ini, dengan rencana tindak lanjut pendampingan usaha baru dibidang fashion dan kerajinan berbahan kain shibori ini.

\section{Ucapan Terima Kasih}

Ucapan terima kasih disampaikan kepada Pimpinan UMY dan LP3M UMY yang telah memberikan dukungan finansial berupa dana hibah pengabdian pada masyarakat melalui program PKM. Terima kasih kepada Ibu Sri Jauharotul Maknunah yang telah membantu dalam program pelatihan membuat kain shibori. Selanjutnya terimakasih juga pada Ibu Haryani selaku pimpinan mitra kelompok pengajian ibu-ibu Baitus Sholikhin, dusun Sembuh, Sidomulyo, Godean, yang telah bersedia bekerjasama dalam pelaksanaan kegiatan pengabdian masyarakat ini.

\section{Daftar Pustaka}

Kotler, Philip, dan Keller (2013), "Manajemen Pemasaran”, edisi 13, Penerbit Erlangga: Jakarta Sulistiyani (2014) "Kemitraan dan Model-model Pemberdayaan Perempuan", Yogyakarta, Graha Ilmu.

Zimmerrer (2008), "Kewirausahaan dan Manajemen Usaha Kecil, Edisi 5, Salemba Empat: Jakarta

https://www.republika.co.id/berita/ekonomi/makro/17/10/08/oxi22v299-umkm-yogyakarta-

didorong-masuki-pasar-digital

http://www.aisyiyah.or.id/id/page/majelis-ekonomi-dan-ketenagakerjaan.ht

https://eprints.uny.ac.id/7803/3/BAB\%202-07404244051.pdf 